\title{
Brazilian Market Reaction to Equity Issue Announcements
}

\author{
Otavio Ribeiro de Medeiros \\ Alberto Shigueru Matsumoto
}

\section{RESUMO}

O trabalho relata um estudo de evento para investigar a reação do mercado antes, durante e após os anúncios de emissões de empresas brasileiras, entre 1992 e 2003. Após mensurar os retornos anormais por mínimos quadrados, utilizou-se modelos ARCH e GARCH para 70\% da amostra. Os resultados são consistentes com a literatura internacional. Alguns resultados empíricos antecedentes evidenciaram retornos anormais anteriores ao anúncio, interpretados como indícios de informação privilegiada. Tal evidência também aparece no presente estudo, onde se encontrou um retorno anormal cumulativo médio de $-0,01$ a três dias antes do anúncio. Com relação à data do anúncio, a literatura existente é virtualmente unânime em relatar retornos anormais negativos, significando que emissões de ações transmitem informações pessimistas ao mercado. O presente estudo confirma tais achados com um retorno anormal cumulativo médio de- 0.03 nos três primeiros dias após os anúncios. A literatura empírica também acumulou evidências de retornos anormais negativos no longo prazo após as emissões de ações, o que também foi confirmado na presente pesquisa, com um retorno anormal cumulativo médio de $-0,28$, um ano após os anúncios. Os resultados também mostram que a estimação dos retornos anormais por $\mathrm{ARCH}$ e GARCH é superior àquela realizada por mínimos quadrados.

Palavras-chave: estudo de evento; mercado de ações; retornos anormais; ARCH; GARCH; empresas brasileiras.

\begin{abstract}
We have carried out an event study to investigate stock returns associated with the announcement of equity issues by Brazilian firms between 1992 and 2003 in order to determine market reaction before, during, and after the issue announcement. After measuring abnormal returns by OLS, we used ARCH and GARCH models over 70\% of the sample. Our results are remarkably consistent with most of the international empirical literature. Some previous empirical findings have turned up abnormal returns before the announcement date, interpreted as signs of insider information. This evidence also appears in our study as we found an average cumulative abnormal return of -0.01 three weeks before the announcement. With respect to the announcement date, the evidence reported in the literature is virtually unanimous in showing negative abnormal returns, meaning that stock issues convey pessimistic information to the market. Our study confirms these findings with an average -0.03 cumulative abnormal return on the first three days following the announcement. Finally, the empirical literature has also collected evidence of long-term negative abnormal returns after the issues, which we also confirm, with an abnormal return of -0.28 after one year following the announcement. The results also show that ARCH/GARCH estimation of abnormal returns is superior to OLS estimation.
\end{abstract}

Key words: Brazilian stock market; SEOs; event study; market volatility; GARCH. 


\section{INTRODUCTION}

The empirical evidence on market reactions to equity issues has inspired researchers to develop theories to explain seemingly abnormal results, thus contributing to a better understanding of the phenomena of capital markets. Authors have proposed several hypotheses to explain market reactions to public equity offerings. These may fall into three categories:

a) There is no price effect - in agreement with the hypotheses of an efficient market and considering shares as close substitute goods;

b) There are negative price effects - in agreement with informational effects associated with the issuing of overpriced equities by well-informed sellers, to leveraged-related capital structure hypotheses based upon redistribution of firm value among different classes of stockholders, and to downward-sloping demand curves for shares; and

c) There are positive price effects - consistent with favorable information signaled by investment, and with a reduction in expected costs of financial distress and agency costs.

This paper examines stock returns related to 80 public equity issues by Brazilian firms listed on the Sao Paulo stock market between 1992 and 2003. More specifically, the paper examines whether the behavior of the Brazilian market is consistent with international evidence concerning the market's reaction: (a) from 15 workdays prior to the issue announcement until the day of the announcement; (b) on the day of the announcement and subsequent days; and (c) for one year after the issue.

Initially, the study intends to measure eventual abnormal returns using the usual approach in event studies, i.e. the market model (MACKINLAY, 1997), where the abnormal returns are the residuals of OLS regressions. However, as empirically evidenced (AKGIRAY, 1989; BOLLERSLEV, 1986; CHIANG; DOONG, 2001), it is quite usual for equity returns to follow autoregressive processes with conditionally heteroscedastic innovations, i.e. ARCH processes. Indeed, we have detected processes of this kind in over $70 \%$ of the sample. For these cases, we have replaced the original OLS estimation by $\mathrm{ARCH}$ or GARCH estimations, as necessary, with improved statistical results.

The paper is set out as follows: next Section summarizes theories and previous empirical studies; Section Methods considers the sample and methods used; Section Results analyzes results; and last Section presents the conclusions.

\section{THEORIES AND EMPIRICAL EVIDENCE}

There are several theoretical points of view that attempt to explain market reactions to the announcement of equity public offers. The most relevant theories on the topic can be summarized as follows:

Myers and Majluf (1984) studied corporate financing and investment decisions under the assumption that management is better informed about a firm's value than outside investors. They have shown that in the best interest of existing shareholders, better-informed managers can rationally turn down positive NPV projects. If the market significantly undervalues the company's assets, the dilution suffered by existing stockholders can be greater than any gains they might obtain from undertaking positive NPV projects. Hence, management will turn down equity issues and eventually the project that require equity financing. On the other hand, a decision to issue a new equity and invest in the project could signal an overvaluation of the company's assets. The under/over valuation of assets creates an adverse selection problem. The correct decision (to invest in projects with positive NPV) may be worse for stockholders; on the other hand, investors may find the firm needs financial resources, meaning that its expected future cash flow is not so good, which implies that its shares are 
overvalued. Thus, stock issue announcements may result in negative impacts on the stock price, thereby accounting for the negative abnormal returns.

Miller and Rock (1985) assume that managers know more about a firm's future cash flow than shareholders do, but there is no such informational asymmetry concerning both the level of planned investment and the value of the firm's assets conditional on current cash flow. In their model, the unanticipated decision to issue equity signals bad news about a company's future cash flows to finance its planned investment, which brings about a negative price response. The adverse selection problem and the timing of new issues have been at the core of the Lucas and McDonald (1990) signaling hypothesis. They have presented an asymmetric-information, infinite-horizon model of the equity issue decision predicting that equity issues are on average preceded by an abnormal rise in the market and an abnormal positive return on the stock and that the stock price drops on the announcement of an issue.

Jensen and Meckling (1976) present agency cost implications for the new equity issues. In the United States, a relevant part of executives' compensation is in the form of stock or stock options. Thus, in the decision-making process of issuing equities, agency costs might emerge from the divergence between managers and stockholders. Jensen (1986) relies on agency arguments in predicting market reactions to equity offerings. Managers are the shareholders agents, and because both parties are self-interested, there are serious conflicts between them over the choice of the best corporate strategy. The market reaction to the announcement of an equity offering will depend on its assessment of the probability that the firm will invest in positive NPV projects or not.

Scholes (1972) proposes that stock prices may drop at the announcement of an equity issue because there is a downward sloping demand for a specific security. The model antagonizes the hypothesis of efficient markets where the demand for equity is horizontal and stocks are close substitutes. Scholes' hypothesis rests on the assumption of an incomplete capital market with restricted short sales. Under these conditions, perfect substitutes for a firm's securities do not exist in the market. In the absence of perfect substitutes, firms face downward sloping demand curves for their securities. Scholes' hypothesis also predicts that an increase in quantity caused by a new issue of common stock results in a permanent decrease in the stock price.

Currently, most of the existing empirical evidence supports the view that the market reacts negatively to the announcement of equity offerings. However, Hess and Frost (1982) have investigated price movements in the neighborhood of SEOs' issuing day. They compare three competing hypotheses: the SEC view that a new issue causes a permanent price decline; the underwriter view that there is only a temporary price decline during the distribution period; and the efficient market hypothesis that there are no price effects. They rejected the first two hypotheses in favor of the efficient market hypothesis.

Asquith and Mullins (1986) have shown that the announcement of equity offerings reduces stock prices significantly. They found a mean two-day announcement period excess return for primary issues of $-3.0 \%$. This negative stock price reaction representing the loss in value of the firm on the single announcement day is on average $31 \%$ of the funds raised in the primary offering. The findings are consistent with both the signaling hypothesis where equity issues are conveying negative information to the investors about the true value of the firm, and the price pressure hypothesis that there is a downward sloping demand for securities.

An analysis performed by Mikkelson and Partch (1986) concluded that equity offerings are associated with a positive mean excess return between the announcement and a negative mean return at the issuance. The reason declared for the issue would also affect price response. The study reports a higher price drop in response to common stock issues to refinance debts than to finance capital investments. This evidence is consistent with Myers and Majluf (1984) and the argument that announcements of common stock and convertible security offerings convey that the share price is too high. All types of unexpected new financings present negative price response, which is consistent with 
Miller and Rock's (1985) model leading market participants to lower their assessment of a firm's earnings prospects.

Gerard and Nanda (1993) have developed a model that predicts, inter alia, that, on average, secondary market prices drop in the days preceding the issue day, recover in the post issue market, and that the new shares sell at a discount from the market's expectation on the stock value at the time of issue.

Loughran and Ritter (1995) have shown that companies issuing stock from 1970 through 1990 , whether initial issues or not, significantly underperform relative to non-issuing firms for five years after the offering date. They have also shown that issuing firms have slightly higher betas than nonissuers, implying that issuers should have higher instead of lower returns. In their own words, the reason why firms issuing equity produce such low returns for investors over the next five years constitutes a puzzle

Spiess and Affleck-Graves (1995) and Loughran and Ritter (1997) have shown that, in addition to the negative announcement period returns, issuing firms experience abnormally low stock returns over the five years following the issue. One explanation for these findings is that managers time equity issues to take advantage of windows of opportunity to issue overvalued equity. This explanation requires not only that investors are overly optimistic about the issuing firms' prospects at the time of the issue announcement, but also that investors under-react to information conveyed by the issue. Although Fama (1998) has argued that these results reflect normal random variations that occur in efficient markets, the long-run post-announcement abnormal stock-price performance presents a challenge to the traditional paradigm of market efficiency.

Kadiyala and Rau (2001) developed two conflicting behavioral models, an under-reaction and an over-reaction model, respectively, to explain long-run abnormal return phenomena following corporate events. The study provided evidence that only the investor under-reaction model can explain negative abnormal returns. Investors under-react to short-term information available prior to the event and subsequently to the information conveyed by the corporate event.

Hertzel et al (2002) examined post-announcement stock-price performance for a sample of firms that sell equity through private placements. They have found that despite there being a positive stock-price reaction at the announcement, firms that issue equity privately significantly under-perform relative to several benchmarks over the three-year period following the offering. Furthermore, the negative postannouncement performance documented for private placements is similar to the long-run underperformance reported for initial public issues (IPOs) or seasoned equity issues (SEOs). Taken together, the evidence suggests that investors are too optimistic about the prospects of firms that issue equity, regardless of the form of issuance.

Leal and Amaral (2000) studied the Brazilian market reaction before the announcement of an equity issue sample and verified positive abnormal returns 60 days and 5 days before the announcement, showing possible manipulation by investors with insider information. The authors also verified negative market reactions on the announcement day, in agreement with the extant evidence.

\section{METHODS}

In the present study, we selected 80 public equity issues carried out from 1992 to 2003 by firms listed in the Brazilian stock market. The source of data is the Economatica ${ }^{\circledR}$ database. The study analyzes the abnormal returns observed from 15 working prior to the announcement of the issue to one year after the issue day. The announcement date is the date on which the first information concerning a specific equity issue becomes public in the specialized press. Economatica ${ }^{\circledR}$ compiles and discloses this information, based on the two main Brazilian economic and financial newspapers: Gazeta 
Mercantil and Valor Econômico. We considered these sources to be reliable enough to allow us to use a one-day event window.

We applied the amplified Dickey-Fuller test for unit roots (DICKEY; FULLER, 1979) to verify the stationarity of the 160 sample data series, i.e. the 80 stock return series and the 80 market return series in order to prevent the occurrence of spurious regressions. The literature indicates that the stock prices tend to be non-stationary, while stock returns tend to be stationary (BROOKS, 2002). These results are described in the next section.

The purpose of the methodology used in the study was to verify whether:

a) There are abnormal returns in the period from 15 workdays prior to and the announcement, which would indicate the occurrence of insider information;

b) There are abnormal returns on the announcement day, as documented in previous empirical studies;

c) The long-term performance of stocks belonging to issuing firms is also negative in Brazil, as reported for other markets in the international literature.

There are two types of models used for the empirical study of stock behavior in capital markets: price and return models. Because price models present complex econometric problems, e.g. nonstationarity of price series, return models are more frequently used. In this case, we used a given type of return model in connection with the method known in the literature as event study (BROWN; WARNER, 1985; CAMPBELL; LO; MACKINLAY; 1997; MACKINLAY, 1997).

In the study, we define each event as the announcement of an issue by a listed firm, and the event day is the issue announcement day. The study uses daily returns, considering workdays only. We performed the tests of hypotheses under the null of non-existence of abnormal returns. With the purpose of capturing possible abnormal returns in the event window, we initially estimated the market model by OLS.

\section{Measurement of Abnormal Returns by OLS}

There are alternative methods for computing abnormal returns, either by means of statistical or economic models. If the market model is used, abnormal returns are equal to the difference between the actual stock returns and the predicted stock returns based on OLS estimation, with market return as the exploratory variable. We can write this as:

$\mathrm{AR}=\mathrm{R}-\mathrm{R}^{*}$

where $\mathrm{AR}$ is the abnormal stock return of the $i$-th share on time $t, \mathrm{R}$ the actual stock return and $\mathrm{R}^{*}$ is the predicted return. The regression equation used to estimate parameters is:

$\mathrm{R}=\mathrm{R}_{\mathrm{m}} \beta+\mathrm{u}$

$\mathrm{R}_{\mathrm{m}}$ is a matrix with elements of the first column equal to one and the second column formed by market returns through time. $\beta$ is a column vector with the regression parameters and $u$ is the column vector of random terms $u_{t}$, assumed i.i.d. $\sim \mathrm{N}\left(0, \sigma^{2}\right)$. The predicted return is:

$\mathrm{R}^{*}=\mathrm{R}_{\mathrm{m}} \hat{\beta}$

with $\hat{\beta}=\left(R_{m}^{\prime} R_{m}\right)^{-1} R_{m}^{\prime} R$, 
where $\hat{\beta}$ is the vector of the linear regression estimated parameters for an estimation window prior to the event, and $R_{m}$ is the matrix of market returns. In this study, the estimation window adopted for all sample events was of 105 working days. Assuming that the $\mathrm{R}_{\mathrm{m}}$ elements are exogenous with respect to $\mathrm{R}$, the $\hat{\beta}$ parameters are unbiased and consistent estimations. Combining (2) and (3) results in:

$\mathrm{AR}=\mathrm{R}-\mathrm{R}_{\mathrm{m}} \hat{\beta}$

The aggregation of abnormal returns across a sample of size $N$ is:

$\overline{\mathrm{AR}}=\frac{1}{N} \sum_{i=1}^{N} \mathrm{AR}$

We also accumulate the average daily abnormal returns obtained in (6) through time. Defining $\overline{\mathrm{CAR}}\left(\tau_{1}, \tau_{2}\right)$ as the column vector components of the cumulative abnormal returns between dates $\tau_{1}$ and $\tau_{2}$, we have

$\overline{C A R}\left(\tau_{1}, \tau_{2}\right)=\sum_{\tau_{1}}^{\tau_{2}} \overline{A R}$

Under the null hypothesis that the $\overline{C A R}\left(\tau_{1}, \tau_{2}\right)=0$, we have

$\theta=\frac{\overline{C A R}\left(\tau_{1}, \tau_{2}\right)}{\left[\operatorname{var}\left(\overline{C A R}\left(\tau_{1}, \tau_{2}\right)\right]^{1 / 2}\right.} \square N(0,1)$

\section{Measurement of Abnormal Returns by ARCH/ GARCH}

Bollerslev (1986), Akgiray (1989) and Chiang and Doong (2001) have shown that the daily stock returns present variable volatility over time, thus tending to show ARCH (Autoregressive Conditionally Heteroscedastic) effects. In this study, we decided to check for this occurrence by using the Engle (1982) test. Indeed, in 58 out of the 80 regressions associated with the events that compose the sample, we were obliged to reject the null of non-existence of ARCH effects. In this situation, the estimation by OLS is biased and inconsistent, since the assumption that the residuals are i.i.d $\sim \mathrm{N}\left(0, \sigma^{2}\right)$ is violated. For this reason, when detecting the presence of those effects, the regressions represented by (2) were re-estimated using ARCH or GARCH (Generalized Autoregressive Heteroscedastic) models. After running, tuning, and choosing the best regressions, from the 58 cases, 13 resulted in $\mathrm{ARCH}(1)$ processes whereas 45 resulted in $\operatorname{GARCH}(1,1)$ processes. When a $\mathrm{GARCH}(1,1)$ model is considered, the specification (2) is replaced by:

$\mathrm{R}=\mathrm{R}_{\mathrm{m}}+\mathrm{u} \quad u_{i t} \sim N\left(0, \sigma_{i t}^{2}\right)$, where

$\sigma_{i t}^{2}=\alpha_{i 0}+\alpha_{i 1} u_{i t-1}^{2}+\alpha_{i 2} \sigma_{i t-1}^{2}$

This specification becomes an ARCH (1) process if $\alpha_{\mathrm{i} 2}=0$.

The set of methods used in this study also included the White (1980) test for heteroscedasticity, the Jarque-Bera non-normality test (BERA; JARQUE, 1981), and the Durbin-Watson test for residuals autocorrelation (DURBIN; WATSON, 1951). We also used the Cochrane-Orcutt estimation method (COCHRANE; ORCUTT, 1949) when we detected autocorrelation in the OLS residuals. 


\section{RESULTS}

The augmented Dickey-Fuller test allowed us to reject the presence of unit roots in all series at the level of $1 \%$, so that we can consider the series as stationary. On the other hand, the Jarque-Bera nonnormality test revealed evidence of Gaussian residuals in 39 regressions, but the remaining ones (41) showed non-normal residuals. The normality of residuals is necessary to validate the t-tests. Fortunately, considering that in half of the sample the residuals were accepted as Gaussian and the fact that the sample is sufficiently large $(N=80)$, the residuals' normality violation in the other half of the sample is practically harmless, given the Central Limit Theorem. Concerning the measurement of abnormal returns by OLS, according to equation (2), the Durbin-Watson test revealed that in three regressions we have to reject the null hypothesis of non-existence of serial correlation in the residuals. For these regressions, we used the Cochrane-Orcutt estimation method, which eliminates the autocorrelation problem.

Based on previous studies by Bollerslev (1986), Akgiray (1989), and Chiang e Doong (2001), we considered the possibility of existence of ARCH effects in the regression residuals obtained by OLS. Accordingly, we decided to apply the Engle (1982) test in the residuals of all 80 regressions, and we found the occurrence of these effects in 58 regressions. For this reason, we also decided to re-estimate these regressions using $\mathrm{ARCH}(1)$ or $\operatorname{GARCH}(1,1)$ models, according to equations (9) and (10) above. GARCH $(1,1)$ models fitted better in 45 cases and ARCH(1) in 13 cases. We maintained the original regressions by OLS for the 22 remaining regressions, which had shown no signs of heteroscedasticity. The regressions obtained by ARCH or GARCH have proved to be significantly superior to those estimated by OLS in terms of the t-test, the F test and $\mathrm{R}^{2}$. White's (1980) residuals test did not reveal the existence of other heteroscedastic patterns besides ARCH processes.

Graph 1 shows two series of daily cumulative abnormal returns: (a) those obtained with estimation by OLS for the whole sample and (b) those obtained by ARCH for 13 events, GARCH for 45 events, and OLS for 22 events.

\section{Graph 1: Cumulative Abnormal Returns}

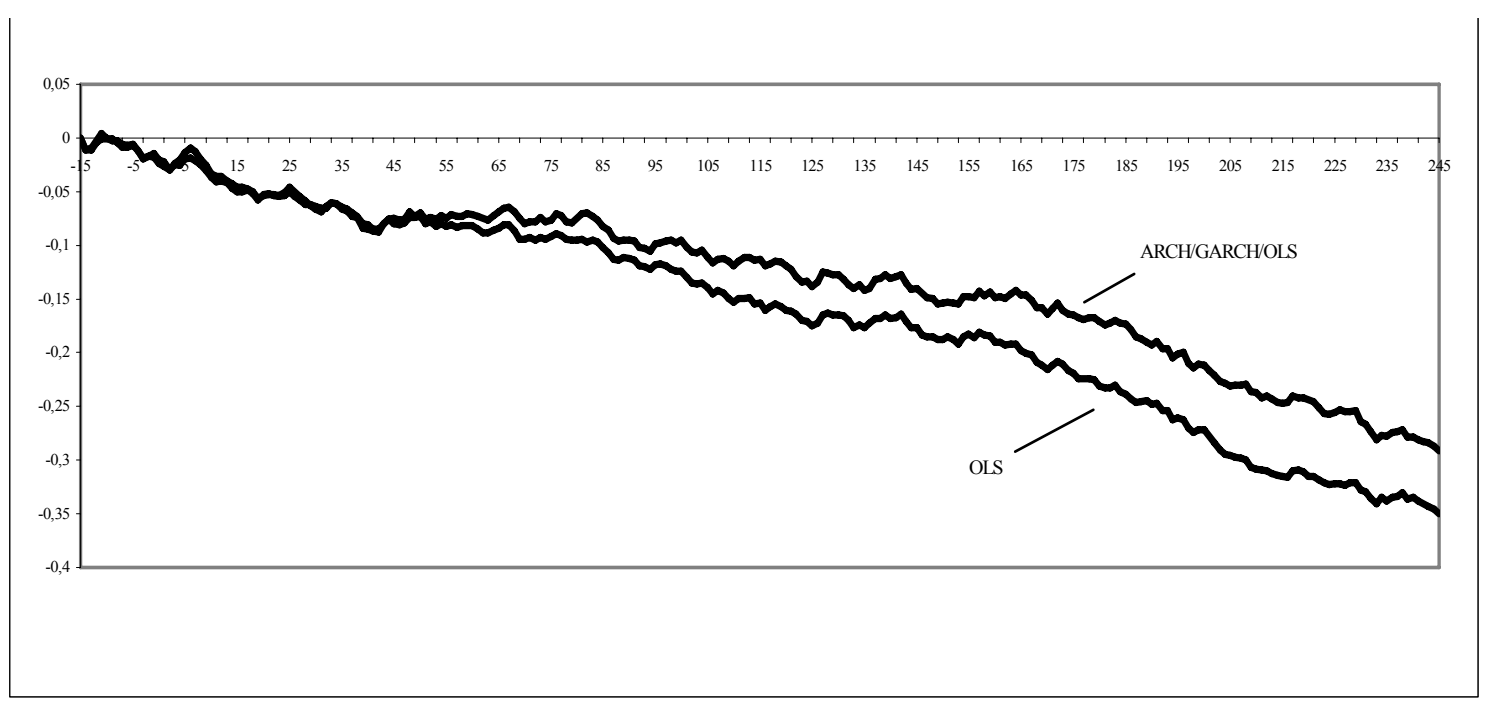

We can see that the estimation results by OLS only show lower abnormal returns if compared to the OLS/ARCH/GARCH combined estimation, indicating that there is a downward bias in the single OLS estimation, as shown in previous studies (AKGIRAY, 1989). However, we can see that re-estimation of part of the sample by ARCH or GARCH does not alter the general conclusions with regard to the market reaction. 
Table 1 shows the simple and accumulated daily abnormal returns and corresponding $\mathrm{t}$ statistics estimated by OLS, ARCH or GARCH, according to their best fit, for the period of 15 days prior to and 15 days following the issue announcement. We observe the occurrence of significant negative abnormal returns on the $14^{\text {th }}$ and $13^{\text {th }}$ days prior to the announcement followed by non-significant returns. We also observe significant negative abnormal returns on the issue announcement day and on the two subsequent days. Abnormal returns are not significant between the $3^{\text {rd }}$ and $9^{\text {th }}$ day after the announcement, but from the $10^{\text {th }}$ day onwards, until the end of the period of approximately one year (in working days), the negative abnormal returns are significant.

Based on these empirical results, we can say that:

a) The market reaction to the issues in the pre-announcement period shows a negative abnormal return 14 working days before the announcement ( 3 weeks), which seems to indicate the occurrence of insider information, since this is an anticipated reaction that should occur on the announcement day only;

b) There are cumulative negative abnormal returns on the announcement day and on the two subsequent days; and

c) The market reaction throughout approximately one year after the issue announcements indicates a persistent negative stock performance.

Table 1: Abnormal Returns (AR), Cumulative Abnormal Returns (CAR), and t Statistics, Estimated by ARCH, GARCH and OLS

\begin{tabular}{|c|c|c|c|c|c|c|c|}
\hline day & AR & CAR & $\mathrm{t}(\mathrm{CAR})$ & day & AR & CAR & $\mathrm{t}(\mathrm{CAR})$ \\
\hline-14 & -0.011 & -0.011 & $-3.011 *$ & +1 & $\begin{array}{c}-0.003 \\
\end{array}$ & -0.027 & $-1.833^{*}$ \\
\hline-13 & 0.000 & -0.011 & $-2.080 *$ & +2 & \begin{tabular}{c|}
-0.003 \\
\end{tabular} & -0.030 & $-1.986 *$ \\
\hline-12 & 0.007 & -0.004 & -0.624 & +3 & 0.006 & -0.024 & -1.523 \\
\hline-11 & 0.003 & -0.001 & -0.077 & +4 & 0.003 & -0.020 & -1.278 \\
\hline-10 & -0.001 & -0.001 & -0.160 & +5 & 0.006 & -0.014 & -0.857 \\
\hline-9 & 0.000 & -0.001 & -0.133 & +6 & 0.004 & -0.010 & -0.588 \\
\hline-8 & -0.003 & -0.004 & -0.406 & +7 & -0.003 & -0.012 & -0.727 \\
\hline-7 & -0.004 & -0.008 & -0.799 & +8 & -0.007 & -0.020 & -1.119 \\
\hline-6 & 0.000 & -0.008 & -0.775 & +9 & -0.006 & -0.026 & -1.427 \\
\hline-5 & 0.002 & -0.007 & -0.589 & +10 & -0.007 & -0.033 & $-1.797 *$ \\
\hline-4 & -0.005 & -0.012 & -0.988 & +11 & -0.003 & -0.036 & $-1.911 *$ \\
\hline-3 & -0.008 & -0.020 & -1.567 & +12 & 0.000 & -0.036 & $-1.885 *$ \\
\hline-2 & 0.002 & -0.017 & -1.325 & \begin{tabular}{ll|}
+13 \\
\end{tabular} & -0.004 & -0.040 & $-2.084 *$ \\
\hline-1 & -0.001 & -0.018 & -1.333 & +14 & \begin{tabular}{c|c|}
-0.03 \\
\end{tabular} & -0.043 & $-2.185 *$ \\
\hline 0 & -0.006 & -0.024 & $-1.681 *$ & +15 & \begin{tabular}{c|}
-0.003 \\
\end{tabular} & -0.046 & $-2.293 *$ \\
\hline
\end{tabular}

\section{CONCLUSION}

In this paper, we have undertaken an event study on the market reaction to a sample of 80 SEOs issued on the Brazilian stock market from 1992 to 2003. Initially, we computed abnormal returns for each issue using the market model estimated by OLS. We verified, however, the presence of ARCH processes in the regression residuals in $70 \%$ of cases. For these cases, we re-estimated the regressions 
by ARCH or GARCH models, according to their best fit. Comparing the initial results to those that take into account the heteroscedastic processes, we verified that the original results indicate negative abnormal returns biased downwards with respect to the alternative estimation. However, the reestimation, despite leading to lower abnormal returns in absolute values, does not qualitatively alter the results.

The results show that the stockholders seem to be cautious when it comes to firms that issue stock to raise funds with the argument that they are investing in projects with positive NPV. When firms announce that they are raising funds through the issue of new stocks, we can infer that these firms could be waiting for an opportunity window to issue. Therefore, when the stock market reaches a given level in which the shares of these firms are overvalued, stockholders are satisfied to sell part of their investment at a profit. Actually, this shows that when companies announce the issue, there is negative signaling to the market, which is in agreement with Myers and Majluf (1984), and Miller and Rock (1985).

As demonstrated in this study, in the period of 1992 to 2003, Brazilian companies that raised funds through underwriting were unable to meet the benchmark, i.e. the Brazilian stock market index. One may infer that those with insider information sell their equity position about three weeks before the announcement, as they expect the announcement will convey negative information about the firm's true value. The general conclusion is that there are significant negative abnormal returns about 3 weeks before the announcement, indicating the occurrence of inside information, which would anticipate what should only occur on the announcement day.

The results presented negative CARs of 4.6\% 30 days around the announcement day, i.e. 14 days before and 15 days after. On the announcement day, we found a negative abnormal return (AR) of $2.4 \%$. We can say that the results obtained are consistent with most of the previous empiric evidence, both in terms of negative abnormal returns resulting from the announcement, as well as throughout the following twelve months. The results seem to show that the market reaction to non-initial public equity issues in Brazil is not very different from that observed in the United States, at least when the period of one year is considered.

Comparing these results with the discussions presented in second and third sections, we can say that they are consistent with the existing theoretical and empirical framework. We can interpret the occurrence of negative abnormal returns three weeks before the issue announcement as evidence of insider information, since it seems to be an anticipation of what should occur only on the announcement day. However, this result is not in agreement with the results obtained by Leal and Amaral (2000) with regard to the pre-announcement period, since they found positive abnormal returns 60 and 5 days before the announcement. The result of the present study concerning what happens on the announcement day, however, is in agreement with Leal and Amaral (2000).

The negative abnormal returns related to the announcements are consistent with the asymmetric information hypothesis in which the management has better information about a firm's value than outside investors. More specifically, the results are in agreement with the hypotheses by Myers and Majluf (1984), and Miller and Rock (1985) that the issue conveys negative information concerning the future prospects of firms.

Our outcome does not contradict Lucas and McDonalds' (1990) signaling hypothesis. Although their model predicts that stock issues are on average preceded by an abnormal rise in the market and an abnormal positive return on the stock, which was not observed in our study, it also accounts for market-relative price drops, i.e. negative abnormal returns following the issues.

The results here presented are also in agreement with Scholes (1972), Jensen and Meckling (1976), Asquith and Mullins (1986), Myers and Majluf (1984), Miller and Rock (1985), Spiess and AffleckGraves (1995), and Loughran and Ritter (1995). These studies report negative abnormal returns in the long-term after the issues announcement. The upshot here obtained does not confirm the predictions of the model of Gerard and Nanda (1993) in which secondary market prices will on average drop on the 
days preceding the issue day and recover on the post-issue market, since such recovery was not verified. Similarly, when we compare our results to those of Hess and Frost (1982), we cannot confirm their conclusion that one should reject the SEC view (permanent price decline) and the underwriter view (temporary price decline) in favor of the efficient market hypothesis (no price effect).

Artigo recebido em 09.02.2005. Aprovado em 07.07.2005.

\section{REFERENCES}

AKGIRAY, V. Conditional Heteroscedasticity in Time Series of Stock Returns: Evidence and Forecasts, Journal of Business, Chicago, IL, v. 62, n.. 1, p. 55-80, Jan. 1989.

ASQUITH, P.; MULLINS, D.W. Jr. Equity Issues and Offering Dilution, Journal of Financial Economics, Rochester, N.Y., v. 15, n. 1, p. 61-89, Jan. 1986.

BERA, A.K.; JARQUE, C.M. An Efficient Large-Sample Test for Normality of Observations and Regression Residuals, Australian National University Working Papers in Econometrics n. 40, Canberra, AU, 1981. (working paper).

BOLLERSLEV, T. Generalized Autoregressive Conditional Heteroscedasticity, Journal of Econometrics, Amsterdam, v. 31, issue 3, p. 307-327, Apr. 1986.

BROOKS, C. Introductory Econometrics for Finance, 1 th ed. Cambridge, UK: Cambridge U. Press, 2002. Chapter 7.

BROWN, S. J.; WARNER, J. B. Using daily stock returns: the case of event studies. Journal of Financial Economics, Amsterdam, v. 14, issue 1, p. 3-31, March 1985.

CAMPBELL, J. Y.; LO, A. W.; MACKINLAY, A. C. The Econometrics of Financial Markets, 1 th ed. Princeton, N.J.: Princeton University Press, 1997.

CHIANG, T.C.; DOONG, S.C. Empirical Analysis of Stock Returns and Volatility: Evidence from Seven Asian Stock Markets Based on TAR-GARCH Model, Review of Quantitative Finance and Accounting, Amsterdam, NE, v. 17, n. 3, p. 301-318, Nov. 2001.

COCHRANE, D.; ORCUTT, G.H. Application of Least Squares Regression to Relationships Containing Autocorrelated Error Terms, Journal of the American Statistical Association, Alexandria, VA., v. 44, n. 245, p. 32-61, Mar. 1949.

DICKEY, D.A.; FULLER, W.A. Distribution of Estimators for Time Series Regressions with a Unit Root, Journal of the American Statistical Association, Alexandria, VA., v. 74, n. 366, p. 427-31, June 1979.

DURBIN, J.; WATSON, G.S. Testing for Serial Correlation in Least Squares Regression, Biometrika, London, UK, v. 38, n. 1/2, p. 159-71, June 1951.

ENGLE, R.F. Autoregressive Conditional Heteroskedasticity with Estimates of the Variance of United Kingdom Inflation, Econometrica, Evanston, IL, v. 50, n. 4, p. 987-1007, July 1982.

FAMA, E. Market efficiency, long-term returns, and behavioral finance, Journal of Financial Economics, Amsterdam, NE, v. 49, issue 3, p. 283-306, Sept. 1998.

GERARD, B.; NANDA, V. Trading and manipulation around Seasoned Equity Offerings, Journal of Finance, Oxford, UK, v. 48, n. 1, p. 213-245, Mar. 1993.

HERTZEL, M. et al. Long-run Performance Following Private Placements of Equity. Journal of Finance, Oxford, UK, v. 57, n. 6, p. 2595-2617, Dec. 2002. 
HESS, A. C.; FROST, P. A. Tests for price effects of new issues of seasoned securities, Journal of Finance, Oxford, UK, v. 37, n. 1, p. 11-25, Mar. 1982.

JENSEN, M.C. Agency Costs of Free Cash Flow, Corporate Finance and Takeovers, American Economic Review, Boston, MA, v. 76, n. 2, p. 323-329, May 1986.

JENSEN, M. C.; MECKLING, W. H. Theory of the Firm: Managerial Behavior, Agency Costs and Ownership Structure, Journal of Financial Economics, Amsterdam, NE, v. 3, issue 4, p. 305-360, October 1976.

KADYIALA, P.; RAU, P. R. Investor reaction to corporate event announcements: under-reaction or over-reaction? Journal of Business, Chicago, IL, v. 77, issue 2, p. 357-386, June 2001.

LEAL, R.P.C.; AMARAL, A.S. Um Momento para o Insider Trading: o período anterior ao anúncio de uma emissão pública de ações. In: LEAL, R.P.C.; COSTA Jr., N.C.A.; LEMGRUBER, E.F. (Org.), Finanças Corporativas, 1. ed. Cap. 11, p. 158-173, Coleção COPPEAD de Administração, São Paulo: Atlas, 2000.

LOUGHRAN, T.; RITTER, J. The New Issues Puzzle, Journal of Finance, Oxford, UK, v. 50, p. 2351, Mar. 1995.

The Operating Performance of Firms Conducting Seasoned Equity Offerings, Journal of Finance, Oxford, UK, v. 52, issue 5, p.1823-1850, Dec. 1997.

LUCAS, D. J.; MCDONALD, R. L. Equity Issues and Stock Price Dynamics, Journal of Finance, Oxford, UK, v. 45, issue 4, p. 1019-1043, Sept. 1990.

MACKINLAY, A.C. Event studies in economics and finance. Journal of Economic Literature, Nashville, TN, v. 35, Issue 1, p. 13-39, Mar. 1997.

MIKKELSON, W. H.; PARTCH, M. M. Valuation Effects of Security Offerings and the Issuance Process, Journal of Financial Economics, Amsterdam, NE, v.15, issues 1-2, p. 31-60, Jan./Feb. 1986.

MILLER, M. H.; ROCK, K. Dividend Policy under Asymmetric Information, Journal of Finance, Oxford, UK, v. 40, issue 4, p. 1031-1051, Sept. 1985.

MYERS, S. C.; MAJLUF, N. S. Corporate Financing and Investment Decisions When Firms Have Information that Investors Do Not Have, Journal of Financial Economics, Amsterdam, NE, v. 13, issue 2, p.187-221, June 1984.

SCHOLES, M. The Market for Securities: Substitution versus Price Pressure and the Effects of Information on Stock Prices, Journal of Business, Chicago, IL, v. 45, n. 2, Apr. 1972.

SPIESS, D. K.; AFFLECK-GRAVES, J. Under-performance in long-run stock returns following seasoned equity offerings, Journal of Financial Economics, Amsterdam, NE, v. 38, issue 3, p. 243-267, July 1995.

WHITE, H. A Heteroskedasticity-Consistent Covariance Matrix Estimator and a Direct Test for Heteroskedasticity, Econometrica, Evanston, IL, v. 48, n. 4, p. 817-38, May 1980. 